\title{
CORRIGENDUM Shanghai flora: the politics of urban greening in Maoist China - CORRIGENDUM
}

\author{
HANCHAO LU \\ Doi: https://doi.org/10.1017/S0963926817000396, Published by Cambridge \\ University Press, 22 December 2017.
}

The original version of this article was published with the incomplete author affiliation. The affiliation should have appeared as:

\section{HANCHAO LU}

School of History and Sociology, Georgia Institute of Technology, 221 Bobby Dodd Way, Atlanta, GA 30332-0225, USA

The author and Cambridge University Press apologize for this omission.

\section{Reference}

LU, H. (2017). Shanghai flora: The politics of urban greening in Maoist China. Urban History, 1-22. Published online: 22 December 2017: 14 December 2017. doi:10.1017/S0963926817000396 